\title{
Yeni Medya Ortamlarında İzleyici Seçimi ve Öneri Algoritmaları Netflix Örneği
}

\section{Sedat Özel}

Kocaeli Üniversitesi Illetișim Fakültesi

https://orcid.org/0000-0002-8280-1930

sedatozel@kocaeli.edu.tr
Deniz Özay

Kocaeli Üniversitesi Iletișim Fakültesi

https://orcid.org/0000-0002-3727-9151

deniz.yilmaz@kocaeli.edu.tr

\section{Öz}

Bu çalıșma, algoritmaların tüketici kararlarında ne derece etkili olduğunu ve buna bağlı olarak kișiselleștirme/özelleștirme gibi uygulamaların algoritmik art alanında izleme pratiklerini nasıl maniple ettiğini incelemeyi hedeflemiștir. Bu hedef doğrultusunda, yarı yapılandırılmıș soru formu olușturularak, amaçlı örneklem tekniğiyle belirlenen 8 Netflix kullanıcısıyla 'derinlemesine görüșme' gerçekleștirilmiștir. Böylece, kullanıcıların yeni medya mecralarındaki tercih ve tüketim davranıșları ile öneri algoritmaları arasındaki ilișki üzerine veriler elde edilmeye çalıșılmıștır. Elde edilen bulgular bağlamında Netflix arayüz, kișiselleștirme ve öneri özelliklerinin, izleme pratiklerini yönlendirdiği sonucuna ulașılmıștır. Bu yönlendirmenin özellikle Netflixin belirlediği içeriklerin izlenmesini sağlayacak bir pazarlama stratejisine hizmet ettiği düșünülmektedir. Ayrıca kullanıcıların izleyecekleri içeriği bulma/tercih etme yolu olarak Netflixin tavsiye sistemlerini kullandığı, arayüzün içerik aramada kendi önerilerine ve listelerine yönlendirecek șekilde tasarlandı̆̆ı, bu listelerde ve ana ekrandaki tanıtımlarda Netflixin ön plana çıkarmak istediği yapımların yer aldığı ve içeriğin sunușunun hızlı tüketime uygun olarak kurgulanmasından dolayı tüm katılımcıların 'tıkınırcasına izleme (binge watching)' pratiğine sahip olduğu çalıșmanın ulaștığı bulgular arasındadır.

Anahtar Kelimeler: Kișiselleștirme, Özelleștirme, Arayüz, Netflix, Tıkınırcasına İzleme

Makale Geliș Tarihi: 23.12.2020 • Makale Kabul Tarihi: 23.03.2021

http://ilefdergisi.org

ilef dergisi - () 2021 • 8(2) • güz/autumn: 297-324

Araștırma Makalesi DOI: 10.24955/ilef.1023026 


\section{Audience Selection and}

\section{Recommendation Algorithms}

in New Media

The Netflix Case

\section{Sedat Özel}

Kocaeli University Faculty of Communication

https://orcid.org/0000-0002-8280-1930

sedatozel@kocaeli.edu.tr

\author{
Deniz Özay \\ Kocaeli University Faculty of Communication \\ https:/lorcid.org/0000-0002-3727-9151 \\ deniz.yilmaz@kocaeli.edu.tr
}

\section{Abstract}

This study aims to examine the extent to which algorithms are effective in consumer decisions and how Netflix applications such as personalization and customization manipulate viewing practices with regards to the algorithmic backgrounds of these applications. In line with this aim, a semi-structured questionnaire was created, and an 'in-depth interview' was conducted with 8 Netflix users who determined through the purposeful sampling technique. In this way, the study collected data on the relationship between preferences and consumption behavior of users in new media and recommendation algorithms. In the context of the findings, it was concluded that Netflixs interface, as well as its personalization, and recommendation features manipulate the viewing practices of its users. It is thought that this manipulating effect specifically serves as a marketing strategy that will drive users to watch the content previously determined by Netflix. Among the other findings of the study: As a way of finding or choosing the content to watch, users benefit from the recommendation system served by Netflix; the interface has been designed to guide users to recommended content and lists; the productions Netflix wants to highlight are displayed in these lists and on the main screen; all users practice "binge-watching" as the content has been tailored for fast consuming.

Keywords: Personalization, Customization, Interface, Netflix, Binge Watching

Received: 23.12.2020 • Accepted: 23.03.2021

http://ilefdergisi.org

ilef dergisi • (1) 2021 • 8(2) • güz/autumn: 297-324

Research Article DOI: 10.24955/ilef.1023026 
Teknolojik ilerleme ve entegrasyon sonucu yeni medya ortamlarının kullanıclya sunduğu olanak ve kolaylıklar, geleneksel medya ürünlerinin üretim ve tüketim süreçlerinin mantığını da değiştirmiştir. Geleneksel medyanın yapısı gereği hitap ettiği kitleyi edilgen olarak tasarımlamasına karşın yeni medyanın, kullanıcısına ihtiyaçları doğrultusunda farklılaştırılmış içerikler ve onları seçebilme özgürlüğü verdiği dolayısıyla da aktif bir kullanıcı davranışı oluşturduğu dile getirilir. Yeni medyada üretim süreci kullanıcı odaklı interaktif bir ilişkiyi içermektedir ve teknolojik olanaklar sayesinde yeni medyanın tüketimi de zamandan ve mekândan bağımsızlaştırılmış ve kişiselleştirilmiş tüketim biçimine dönüşmüştür. Kişiselleştirme kavramı genel olarak, kullanıcının davranışları ve/veya kişisel bilgileri doğrultusunda dijital medya içeriklerinin yeniden biçimlenmesi sürecini ifade etmektedir (Blom \& Monk, 2009, s. 195-196) (Sundar \& Sampada, 2010, s. 300-301). Dolayısıyla bu süreç, kişiselleştirilmiş hizmetler sağlayan sistemlerin, kullanıcı hakkındaki bilgileri toplaması ve kullanmasını da kapsamaktadır. Öte yandan, yeni medyanın kullanıcıya sağladığı seçim yapabilme ve aktif katılım avantajını kullanıcıdan aldığı bilgiler ile biçimlendirmesinin ötesinde bu bilgilerin kullanım biçimlerindeki muğlaklık, tartışmaları da beraberinde getirir. İnternet üzerinden verilen birçok hizmette, algoritmik üretim ve yazılım performansları kulla- 
nıcının verilerinden hareketle gelecekteki potansiyel seçimlerini öngörmekte, belirlemekte ve öneri biçiminde yeniden kullanıcıya iletmektedir. Tavsiye sistemleri (recommender systems) olarak nitelenen bu yazılımlar aracılığıyla tüketicinin demografik verileri, karar alma süreçleri, geçmiş satın alma davranışları analiz edilmekte, bu analizden çıkan sonuçlara göre yeni ürünler önerilmekte, kullanıcının neyi alacağına dair karar vermesine yardımcı bir süreç yürütülmektedir (Schafer, Riedl, \& Konstan, 2000, s. 3-4).

Aslında böylesi bir yaklaşım ilk başta kullanıcı yararına ve oldukça masum görünmekle birlikte yeni medya tasarımını tüketim ve gözetim toplumu bağlamında eleştiriye açmaktadır. Cox'a (2018, s. 441) göre; geliştirilen öneri algoritmaları üzerine inşa edilmiş yazılımlar ile kullanıcılar özelleştirme olanak ve sınırlarını tanımlayabilirken endüstriyel aktörler de kullanıcıların tüketim potansiyellerini net bir biçimde görebilme imkânına kavuşmaktadır. Aslında her bir kullanıcı kitlesel davranışın tahkim edilmesi ve şekillendirilmesini sağlayan; algoritmik süreçler tarafından geri beslenen "endüstriyel izleyici" anlayışına göre kümelenmektedir. Bu anlayışın barındırdığ1 sosyoekonomik vurgu, yeni medyanın üzerine inşa edildiği yüksek hızlı ağlar, ara yüzler, bu ara yüzlerin ardında çalışan algoritmalar ve yazılımların tüketim sürecinde oynadığı rol ile ilişkilidir. Bir anlamda kullanıcının bireysel tercihi analiz edilmekte, elde edilen veriler ile tüketim süreci yönlendirilmektedir.

Bu iddia “yeni medyanın ileri sürülen özgürleşimci doğası ile tezatlık oluşturuyor gibi görünmekle birlikte teknolojinin örtük amaçları düşünüldüğünde" (Özel, 2015) haklı bir varsayıma dönüşmektedir. Bu varsayımdan hareketle çalışmanın temel amacı, yeni medyanın vaat ettiği 'kullanıcı özgürlüğü' iddiasına karşılık, kişiselleştirme ve özelleştirme kavramları ile arayüz mantığının örtük amaçlarına odaklanmaktır. Bununla beraber, iletişim çalışmaları tarihi boyunca medya-toplum-birey ilişkisi önemli bir araştırma konusu olmuştur. Ancak teknolojik ilerleme ve yeni medyanın yaygınlaşmasıyla dönüşen medya içeriklerinin üretim ve tüketim pratikleri, iletişim bilimleri açısından yeni soruları gündeme getirmiştir. Bu sorulardan biri de, temelinde algoritmik bir sistemin olduğu yeni medya mecralarının bireylere ne ölçüde özgürlük tanıdığıdır. Buradan yola çıkarak çalışma, yeni medyanın en dikkat çekici tarafı olan kullanıcıya atfettiği sorumluluğu sorgulamakta ve yeni medyada kullanıcı özgürlüğü kavramını yeniden tartışmaya açmaktadır.

Yeni medya, pazarlama stratejisini oluştururken, homojen olmayan toplum yapısını dikkate almakta ve farklı demografik/kültürel özelliklere sahip 
olan kullanıcılara kişiselleştirilmiş geniş bir içerik yelpazesi sunmaktadır. Bu bilgi ışığında, yeni medyanın üretim-tüketim süreçleri üzerine yapılan tartışmalar çalışmanın amacı çerçevesinde incelenmiş ve kişiselleştirme/özelleştirme kavramları ile algoritmaların seçimlere etkisi bağlamında yeniden ele alınmıştır. Tartışmalardan elde edilen bulgular eşliğinde sınırlı bir örneklem üzerinden analiz hedeflenmiştir. Bu bağlamda son yıllarda küresel olarak dikkat çekici bir yükseliş yaşayan ve günümüz izleme pratikleri ile çok yakın ilişkisi nedeniyle de başarılı bir hizmet uygulaması olarak tanımlanabilecek Netflix'in abonelerine sunduğu öneri sistemi, kullanıcı pratikleri açısında incelenmiştir. Netflix, kullanıcıların izleme profili oluşturma, geçmiş izleme tercihleri ve izleme davranışlarına dayanan bir öneri sistemi kullanmaktadır. Ancak bu öneri sisteminin bir noktada kullanıcı tercihlerini örtük bir biçimde yönlendirdiği düşünülmektedir. Dolayısıyla bu yönlendirmenin marka pazarlamasında da aktif olarak ön plana çıkarılan orijinal içerik etiketi etrafında yoğunlaştığı varsayılmaktadır. Bu varsayım ekseninde kullanıcıya önerilen içerik ve kullanıcı seçimleri arasındaki ilişkiselliği analiz edebilmek gerekmektedir. Bunun için amaçlı örneklem tekniği ile belirlenen 8 ayrı demografideki Netflix abonesinin beğeni-izleme pratiklerine odaklanılmıştır. Seçilen kişilerin tercihleri doğrultusunda şekillenen sayfa arayüzleri incelenmiş ve yarı yapılandırılmış görüşme tekniği ile Netflix öneri sistemine yaklaşımları üzerine veriler elde edilmiştir.

\section{Kișiselleștirme-Özelleștirme Yeni Medya Kullanıcı Özgürlüğü}

Yeni medyanın çerçevesini oluşturan inovatif gelişmeler, kitle iletişimi içerisinde 'anonimleşen' izler kitlenin yerine; iletişim süreçlerine üretici olarak da aktif katılım sağlayan bireysel kullanıcıları ön plana çıkarmıştır (Özel, 2012, s. 38). Bu kullanıcılar ile medya arasındaki etkileşimi tanımlayan çift yönlü enformasyon akışı, etkileşimli iletişim dinamiği oluştururken bireylere de istek ve ihtiyaçlarına göre tercih yapabileceği özgürlük alanı yaratmıştır. Bireysel kullanıcıların daha aktif rol aldıkları yeni elektronik yayıncılık ortamında araştırmacı ve uygulayıcılar izleyici merkezli bir bakış açısının farkında olmalıdır. Kullanım ve doyumlar yaklaşımı böyle bir bakış açısını sergiler (Özel, 2015). Kendinden önceki iletişim kuramlarına göre insan unsuruna daha fazla odaklanan bu model (Mutlu, 2008, s. 191), bireylerin medya iletilerini seçtiğini, yorumladığını ya da reddettiğini söyleyerek "pasif izleyici" kavramı yerine "aktif izleyici" fikrini benimsemiştir. İzler kitle etkinliği, yarar, amaçlılık, seçicilik ve izleyicinin medyaya katılımı, kullanıcıların medya etkilerinden aldıkları temel doyumların çeşitlerini tanımlamak anlamına gelir. Amaçlı- 
lık paylaşımı, tavsiye etmeyi ve içerik üzerine diğerleri ile tartışmayı içerir. Program seçiciliği hangi programın izleneceğine karar verileceği zaman ne sıklıkta bir değişiklikle bilgi kaynaklarının kullanıldığı bağlamında operasyonel bir süreci tanımlar (Bondad-Brown, Rice, \& Pearce, 2012, s. 474). Bununla beraber yeni medya paradigmasının bir çıktısı olarak görülebilecek kullanıcı özgürlüğünün ve tüketim mantığındaki dönüşümün temel itkilerinden biri, kişiselleştirme/özelleştirme süreçleridir. Literatürde sıklıkla birbiri yerine kullanılan çok sayıda tanıma sahip bu kavramlar, kullanıcı odaklı modeller olmalarından dolayı aynı stratejiye sahip gibi görünseler de, kendilerine özgü birtakım farklılıkları bulunmaktadır.

Kişiselleştirme (personalization) kavramı, yeni medya sistemleri tarafından kullanıcının geçmiş deneyimlerinden verilerin elde edilmesi ve bu verilerle sistem arayüzünün kullanıcıya uyarlanmasını ifade etmektedir (Sundar \& Sampada, 2010, s. 301-302) Diğer bir deyişle kişiselleştirme süreci, yeni medya teknolojilerinin yazılım ve algoritmalarının kullanıcının davranışları ya da kişisel bilgilerinden hareketle, kullanıcıyı tanıması, hatırlaması ve içerikleri bireyin tercih ya da ihtiyaçlarına göre yeniden düzenlemesini içermektedir. Örneğin, oturum açtıktan sonra kullanıcıya adıyla hitap etmek, IP adresleri / posta kodlarına göre yerel haber içerikleri sunmak ya da geçmiş çevrimiçi satın alma tercihleriyle ilişkili yeni ürünler tavsiye etmek kişiselleştirme modelinin sonuçlarıdır. Kişiselleştirmeyi; sistemin işlevselliği, arayüzü, bilgi içeriği ya da ayırt ediciliğinin bireye göre değiştirilerek kişisel ilgi düzeyinin artırılması olarak tanımlayan Blom'a (2000, s. 313-314) benzer şekilde Ho ve Tam da (2005, s. 3375) 'doğru içeriği, doğru kişiye doğru zamanda ve doğru formatta sunmak' biçiminde ifade etmektedir. Dolayısıyla kullanıcıların farklı ihtiyaçları, beklentileri ya da tüketim davranışları sistem tarafından öngörülen değişkenlerdir.

Çevrimiçi kullanıcı heterojenliğini yakalayan kişiselleştirme modeli, bireylerin hem içeriğe yönelik beklentilerindeki farklığı hem de web tabanlı etkileşim araçlarının kullanımı hakkındaki yetenek, bilgi ve tecrübelerini öngörerek ideal filtrelemeyi yapmaktadır (Miceli, Ricotta, \& Costabile, 2007). Nitekim Amazon.com CEO'su Jeff Bazos "Ne kadar müşterimiz varsa o kadar Web mağazamız olması gerekir" diyerek (Schafer, Riedl, \& Konstan, 2000) yeni pazarlama stratejilerindeki kişiselleştirme modelinin önemine vurgu yapmaktadır. Bu nedenle yeni iletişim teknolojilerinin sahip olduğu yazılım ve algoritmalar, potansiyel müşteri olarak her bireyin kişisel verileri ya da 
kullanıcı deneyimleri ile ürünlerin meta bilgilerini eşleştirerek (Schubert \& Koch, 2002, s. 1953-1965), bireylerin satın alma/tüketme davranışlarını ön görülebilir kılmakta ve onlarla ilişkili yeni içerikleri tavsiye edebilmektedir. Sitenin kendisini her bir müşteriye göre uyarlayarak tüketiciye ürün önermesi biçiminde gerçekleşen tavsiye sistemleri de kişiselleştirmenin önemli bir parçasıdır (Schafer, Riedl, \& Konstan, 2000, s. 3-4).

Sıklıkla kişiselleştirme ile aynı çerçeve içerisinde değerlendirilmekle birlikte kendine özgü bir dinamiği olan etkileşimli pazarlama yöntemlerinin bir diğer unsuru ise özelleştirmedir. Özelleştirme (customization) kavramı; ürünlerin ya da hizmetlerin, tüketicinin geçmiş deneyim ya da bilgilerine dayanarak sistem tarafından otomatik olarak uyarlandığı kişiselleştirme modelinin yerine, müşterinin talebi üzerine gerçekleşen bir süreci ifade etmektedir (Montgomery \& Smith, 2009, s. 131). Aynı stratejik pazarlama mantığına dayanan bu iki süreç, içeriği belirleyen ya da biçimlendiren aktörün kim olduğuna bağlı olarak ayrışmaktadırlar. Nitekim kişiselleştirme ve özelleştirme arasındaki en temel farkın adaptasyon sürecinin kontrolünde yattığını söyleyen Treiblemaier ve arkadaşları (2004, s. 2) özelleştirmenin kullanıcı tarafından başlatılan ve yönlendirilen bir süreç olduğunu belirtmektedir. Dolayısıyla kullanıcının içeriği belirlemedeki rolünü vurgulayan asıl etkenin, ürünün kişinin tercihlerine göre uyarlanması ile kişinin ürünü tercihlerine göre yapılandırması arasındaki iş akışı farklılığı olduğu söylenebilir.

Kullanıcı tarafından başlatılan özelleştirilebilir sistemler, içeriği kendi başına uyarlamak yerine kullanıcıların arayüzlerin biçiminde ve içeriğinde değişimler yapabilmesini sağlayan bir dizi olanak tanımaktadırlar (Sundar \& Sampada, 2010, s. 302-303). Bugün ürün ya da hizmet sunan birçok web sayfasının arayüzü kullanıcı tarafından düzenlenebileceği gibi içeriğin kendisi de tüketici isteklerine bağlı olarak tasarlanabilen esnek üretim teknolojilerine sahiptir. Tüketicinin satın almak istediği ürün/hizmetleri ihtiyaç ya da beğenisi doğrultusunda biçimlendirebilmesi, tüketim sürecinin nihai odak noktasını içeriğin niteliğinden, bireyin tercihlerine çevirmiştir. Coner'in (2003, s. 498504) işaret ettiği üzere kullanıcıların kişiselleştirme sürecinde nispeten pasif bir rolü varken ve içerik onlar için sistem tarafından filtrelenirken, özelleştirmede kullanıcılar sitedeki bilgileri aktif olarak yönlendirebilmektedirler. $\mathrm{Bu}$ açıdan özelleştirme, kullanıcı kontrolüne ve katılımına yüksek düzeyde öncelik vermekte, aynı zamanda da kullanıcıları etkileşimli pazarlama teknolojilerinin kaynağı haline getirmektedir. 
Yeni bilgi teknolojilerinin kullanıcıya hem üretim hem de tüketim aşamasında aktif olabileceği etkileşim imkânı sağlaması, sonsuz ihtiyaçlar ve bu ihtiyaçların nihai olarak karşılanmasıyla karakterize olan tüketim toplumu dinamiklerini yeni bir düzeye taşımıştır. Bugün 'izleyici' yerine 'kullanıcı' kavramının geçmesi, kullanım sözcüğünün pasif bir kabulü değil istemli bir eylemi ifade etmesiyle ve yeni medya tüketiminin doğasıyla ilgilidir (Sundar \& Limperos, 2013, s. 505). Bauman'ın (2005, s. 89) 'yaratılmış ihtiyaçlar ve ayartma' kavramlarıyla tanımladığı toplumsal hedonik tüketim biçiminin seri üretimin standart metalarına ya da hizmetlere dayandığı kabul edilmektedir. Ancak teknolojik gelişmelerle web tabanlı ticaret platformlarının iktisadi faaliyetlere dâhil olması ve sağladığı olanaklar, bireylerin tercih ve arzularının başat rol oynadığı, esnek, etkileşimli ve kişiye özel üretim/tüketim yollarını ön plana çıkarmıştır. Kişiselleştirme ve özelleştirme süreçlerinin filtreleme, tavsiye ya da tüketicinin proaktif olarak ürün ya da hizmetleri belirleyebilmesine olanak tanıyan uygulamaları, kullanıcının kişisel ilgi düzeyini artırarak satın alma davranışını etkileyebilmektedir. Bununla beraber alıcıların tükettiği içeriğin doğasını ve seyrini şekillendirebilmesinin psikolojik çekiciliği, kişiselleştirilmiş ve özelleştirilmiş sistemlerin tüketim ağındaki işlevsel yeniliğinin temelini oluşturmaktadır (Sundar \& Sampada, 2010, s. 299).

\section{Arayüzler ve Seçim Özgürlüğü-Özerkliği}

Tüketicinin/kullanıcının sistemle etkileşime girmesini sağlayan ve kullanıcı deneyimini geliştirerek bireylerin tercihlerine göre uyarlanmış içeriklere ulaşmasını ya da onları biçimlendirebilmesini sağlayan araçlar arayüzlerdir. Arayüzler; eldeki cihazın yeteneklerine, ağ bağlantısına ve bireysel kullanıcının faaliyetlerine, konumuna, bağlamına otomatik biçimde adapte olabileceği gibi, çeşitli özelleştirme mekanizmalarıyla kullanıcının kontrolü ve yönlendirmesine de olanak tanıyabilirler (Weld, ve diğerleri, 2003). Bu nedenle kişiselleştirme ile özelleştirme süreçlerinde arayüzlerin, kullanıcıların verilerinden hareketle uyarlanmış içerikleri tavsiye etmesinde ya da kullanıcıların içerikleri uyarlamasında aracı işlevi gördüğü söylenebilir. Arayüzlerin yeni medya ve iletişim teknolojileri bağlamında sunduğu olanaklar, kullanıcılar açısından üretici / tüketici arasındaki çizgiyi bulanıklaştırırken, bireylerin tercihleri doğrultusunda içerikte gerçek zamanlı değişimler yapabilmesini vaat ederler. Böylesi bir süreç geleneksel medya tüketimi mantığına nispeten kullanıcı üretkenliğini ve katılımını artırıyor gibi görünmekle birlikte yeni medya teknolojilerinin bir çıtısı olan bireylerin seçim özgürlüğü olgusu üzerine tartışmaları da beslemektedir. 
Kullanıcılar yeni medya ortamlarının içerikleri ile etkileşime girdikleri üretim/tüketim süreçlerinde inisiyatif kullanarak arayüzleri kişiselleştirebilmekte ve kendilerine göre uyarlayabilmektedir. Bu süreç, kişinin alımlayacağı ya da tüketeceği bilgi, ürün ya da hizmetlere yön vermede kontrolün tamamen kendisinde olduğu izlenimi yaratmaktadır. Bununla birlikte kişiselleştirme de özelleştirme de sınırlı eylem imkânına sahiptir. Nielsen'in belirttiği üzere (1998), kullanıcılar arayüzler aracılığıyla içeriği ihtiyaçlarına uygun olarak yapılandırırken aslında açıkça belirli seçenekler arasında tercih yapmaktadır. Bu tercih yapma olanağı sistem tarafından oluşturulmuş veri havuzundan bireylerin kendisine en uygun olanı seçmesi yoluyla kısmen kullanıcı özerkliği oluşturmakta ancak neyin ve nasıl tüketileceği konusundaki sinırlılıklar sistem tarafından belirlenmektedir.

Daha önce serimlendiği üzere kişiselleştirilmiş sistemler, kullanıcının iş birliği yaparak filtrelediği verilerden, paylaştığı kişisel bilgilerden ya da geçmiş aramalarından yola çıkarak müşterinin ilgisini çekebilecek içerikleri önermektedir (Treiblmaier, Madlberger, Knotzer, \& Pollach, 2004, s. 2). Ancak kullanıcılar, sistemin otomatik olarak davranışlarına nasıl uyum sağladığını kontrol edemedikleri gibi, tavsiye edilen içeriklerin belirlenmesinde de aktif rol oynamazlar. Öte yandan kullanıcı deneyiminin daha belirleyici olduğu ve kullanıcı tarafından yönlendirilen özelleştirme sistemleri de bütünüyle bireye özgü içerik ya da hizmetlerin sunulmasını mümkün kılmaz. Çünkü özelleştirme yoluyla içerikleri ihtiyaçları doğrultusunda yeniden biçimlendirirken, uyarlanabilir sistem bileşenlerinden faydalanmaktadırlar (Treiblmaier, Madlberger, Knotzer, \& Pollach, 2004) (Nielsen, 2009). Dolayısıyla yeni medya bilgi teknolojilerinin, tüketim unsurlarını ya da yollarını belirlemede bireylere kullanıcı özgürlüğü tanıdığı kabulü yerine, pazarlama stratejilerinin belirlediği sınırlılıklar çerçevesinde kısmen kullanıcı özerkliğine izin verdiği yaklaşımı daha doğru olacaktır.

\section{Netflix: Ne İzliyoruz? Ne İzletmek İstiyor?}

İletişim süreçlerindeki yeni kullanıcı/izleyici yapısı ya da dijitalleşmenin ekonomi politiği ekseninde tartışılabilecek geleneksel TV izleme tarzının dönüşümünde, Netflix ayrıcalıklı bir yere sahiptir. Bugün 190'dan fazla ülkede 130 milyona yakın aboneye ulaşan Netflix' in (Netflix, 2020), teknolojik ve endüstriyel gelişmelerin yanı sıra izleyici davranışının dönüşmesinde ve izleme deneyiminin organize edilmesinde öncü rol üstlendiği kabul edilmektedir (Jenner, 
2018). Kullanıcıya sağladığı aktif katılım ve kişiselleştirme olanaklarının yanı sıra tavsiye sistemleri ve tıkınırcasına izleme (binge watching) gibi stratejik pratiklerin, bu öncülüğün temel nedenlerinden olduğu söylenebilir.

Netflix'in geniş ölçekli kullanıcı etkileşim analizinden edindiği veriler, kullanıcıların izleme alışkanlıkları, deneyimleri ve beğenileri hakkında bilgi toplamasına ve bu bilgileri değerlendirmesine olanak tanımaktadır. Her kullanıcının kişisel tercihleri yönünde gerçekleştirdiği izleme pratiği Netflix' in algoritmaları ile sürekli olarak ilişki içerisinde olduğu için, izleme geçmişine dayalı alışkanlıklar ya da değişiklikler sistem tarafından yakalanabilmektedir. Böylece kullanıcı açısından içeriğin çekiciliği ya da izleme tercihleri her değiştiğinde, Netflix algoritmaları yeniden uyarlanarak izleyicinin dikkatinin sürdürülebilirliği sağlanmaktadır. Nitekim Pilipets'e göre (2019, s. 4); Netflix için önemli olan yalnızca potansiyel olarak çekici olabilecek yeni içeriğin doğru tahmin edilmesi değil, aynı zamanda kullanıcıların düzenli olarak izlemeye devam etmesini ve dikkati yitirmemesini sağlama ihtiyacıdır. Bu sebeple bireyin tercihlerine göre uyarlanan arayüz ya da içerik önerileri, kullanıcı açısından izleme kolaylığı sağlamasının yanı sıra daha fazla izlenme ve aboneliğin sürdürülmesi bağlamında pazarlama stratejisi görevi görmektedir. Cihaz ve kullanıcı arasındaki etkileşimde köprü işlevi gören arayüz tasarımları, sistemin işleyişini ve kontrolünü sağlamak amacıyla, kullanıcının amaçlarını, alışkanlıklarını ve kullanıcı deneyimini göz önünde bulundurur (Baranseli, Kaya, \& Şen, 2018, s. 231). Bu nedenle kişinin uygun içeriğe ulaşmasında kolaylık sağlayan arayüz tasarımları aynı zamanda kullanıcı deneyimine yön verme ya da denetleme potansiyeli taşımaktadır. Etkileşim temelli platformları destekleyen yeni medyada arayüzler, grafik-görsel tasarım unsuru olmanın ötesinde; kişiselleştirme, tavsiye sistemleri gibi stratejilerin sistemin işleyişinde görünür kılındığı grafik tasarımından oluşmaktadır. Bu sebeple arayüzler, kullanıcının sistemle etkileşime girmesi için bir köprü işlevi görürken, sistemin de kullanıcı deneyimi ve tercihlerini yönlendirebilmesi için iletişimsel alan açmaktadır. Nitekim Netflix' in arayüzü kişinin beğenileri ve bu beğenilerden yola çıkılarak tavsiye edilen içeriklerden oluşmakta, kullanıcı odaklı stratejisiyle aboneliğin sürdürülmesine yönelik cazibe yaratmaktadır. Bununla birlikte Netflix'in etkin biçimde kullandığı tavsiye sistemleri, temelinde aynı stratejik mantığın bulunduğu ancak kullanıcı etkileşimi ve deneyiminin ön plana çıkarıldığı bir başka pazarlama unsurudur.

Kamusal hayata katılımımızın önemli bir parçası olan ve bizim için en alakalı olduğu düşünülen bilgilerin seçilmesinde giderek daha önemli bir 
rol oynayan algoritmaların, Netflix' in kullandı̆̆ı izleyici katılımını doğrudan etkilediği düşünülmektedir (Burroughs, 2018, s. 10). Netflix' in ürün yeniliklerinden sorumlu başkan yardımcısı Todd Yellin'e göre kullanıcıların sitede izlediklerinin yaklaşık yüzde 80'i insanların aradıklarından değil, Netflix' in önerdiklerinden oluşmaktadır (Greene, 2016, s. 5). Bu bilgi çerçevesinden bakıldığında tavsiye sistemlerinin temelini oluşturduğu söylenen kullanıcı tercihi ya da kullanıcı katılımının önceliği tartışmalı bir noktaya taşınmaktadır. Çünkü kullanıcıların tüketim davranışının analiziyle kişisel verileri işleyen algoritmik süreçler, tavsiye sistemleriyle yeni içerikleri kişilere sunarken, aslında kullanıcı tercih ya da beğenilerini yönlendirme potansiyeli taşımaktadırlar. "Netflix algoritmasının izleyicinin ilgi gösterdiği programları öne çıararak bile seçimleri sınırladığını" belirten Jenner'a göre (2018) sistem, kullanıcının neyi ne zaman izleyeceğine dair karar vermesine izin vermekte ancak yine de izleyicileri belirli kararlara yönlendirmektedir. Dolayısıyla tavsiye sistemlerinin çalışma prensibi -algoritmaların elde ettiği ve ilişkilendirdiği verilerle de olsa- bizim ne izlediğimizden çok sistemin bize neyi izlettiğiyle ilgilidir. Doğrusal TV mantığı ile karşılaştırıldığında izleyiciler, izleme deneyimlerini geliştiren seçenekler üzerinde daha fazla kontrol hakkına sahiptirler ancak tüketim davranışları şirketin belirlediği ekonomik hedefler ya da kültürel sınırlar çerçevesinde biçimlenmektedir. Bu biçimlendirme süreci kapsamında değerlendirilebilecek ve Netflix'e karakteristik özellik veren kavramlardan biri ise tıkınırcasına izleme (binge watching) kavramıdır.

Netflix' in orijinal yapımları olan House of Cards ve Orange Is the New Black 2013 'te gösterime girdiğinde, abonelerin büyük bir kısmının arka arkaya bölümleri izledikleri, bir sezon içeriğini sadece birkaç gün içinde tükettikleri fark edilmiştir (Matrix, 2014, s. 119). Netflix’i doğrusal TV akışından ayıran nedenlerden biri olarak 'tıkınırcasına izleme' aynı zamanda şirket için yeni bir yayın politikasının da kapısını aralamıştır. Tıkınırcasına izleme kavramı, seri hale getirilmiş bir programın birkaç bölümünün art arda izlenmesini ifade ederken, Netflix için bir izleme biçiminden çok içeriğin nasıl izleneceğini belirleyen bir yayıncllık modelini tarif etmektedir. Zündel'in (2019, s. 196-218), kullanıcıların önemli bir süre boyunca kendilerini anlatıya kaptırdıkları hızlı tüketim tarzı olarak tanımladığı 'tıka basa' izleme pratiği, Netflix'in abonelerinin ilgisini devam ettirebilmede en önemli faktörlerden biridir. İçeriğinin büyük bir kısmı, art arda izlenmesi için belirgin bir şekilde yönlendirilmiş kurgusal dizilerden oluşan Netflix, anlatı akışı içinde kaybolan kullanıcıların hem tüketim tarzını hem de tüketim nesnesini kontrol edebilmektedir. Sürekli 
ya da tıkınırcasına izleme biçiminin, Netflix'in kullanım alışkanlıkları oluşturma ve kolaylık yaratma yöntemi olduğu düşünüldüğünde (Rahe, Buschow, \& Schlütz, 2020, s. 8), kullanıcı tercihlerinin kısıtlı katılımından çok, sistemin yönlendirme gücünün belirleyici olduğu ileri sürülür. Dolayısıyla yeni medya teknolojileriyle beraber kullanılmaya başlanan kullanıcı özgürlüğü kavramı, algoritma ve yazılım süreçlerinin örtük müdahalesini göz ardı etmekte ama ortaya çıkan yeni izleyici yapısına da atıfta bulunmaktadır.

Yeni medya endüstrisinin akış hizmetleri, geleneksel TV mantığını dönüştüren, izleyiciyi edinme, iletişim kurma, sınıflandırma ve onların tüketim davranışlarına yön verme yollarını geliştirecek teknolojik olanakları temsil etmektedirler (Pilipets, 2019, s. 3-4). TV izleme alışkanlıklarını değiştiren seri izleme olanağı, zaman ve mekân bağımsızlığı, çoklu cihazların kullanımı ya da kişiselleştirme yoluyla içeriklere ulaşmadaki kolaylıklar, klasik izleyicinin de yeniden tanımlanmasını gerektirmektedir. Bununla beraber algoritmik ve yazılım süreçlerinin kullanıcıları, yerleri, nesneleri ve içerikleri sınıflandırması, izleme pratik ve davranışlarını da değiştirerek 'algoritmik kültür' olarak tanımlanan (Hallinan \& Striphas, 2016, s. 118-119) yeni bir medya tüketim biçimini ortaya koymaktadır. Dolayısıyla doğrusal TV akışı içinde sadece kanal değiştirme ya da kapatma seçeneklerine sahip olan izleyici, artık sistemle etkileşimde bulunabilen ve doğrusal olmayan bir akış içinde izleme biçimine karar verebilen daha aktif bir rol üstlenmektedir. Ancak yine de algoritmik kültürün bir parçası olarak yeni izleyici modeli; endüstrinin sürdürülebilirliğini riske atabilecek belirsizliğin ortadan kaldırılması için algoritmalar tarafından kontrol edilmekte ve yönlendirilmektedir. Burroughs'un (2018) ‘algoritmik kitle' olarak tanımladığı bu yeni izleyici modelinin tercih süreçleri, algoritmalar aracılığıyla elde edilen veriler doğrultusunda sistem tarafından etkilenebilmektedir. Bu bağlamda; algoritmaların bireyler hakkında onların bildiklerinden daha fazla bilgi sahibi olacağı teknik süreçlere dair öngörüsü bildiren Leonard'ın (2013), yeni izleyicilerin "mutlu abonelerin kuklaya dönüşüp dönüşmediği" sorusu, yeni medya teknolojilerinde kullanıcı özgürlüğü sorunsalına atıfta bulunmaktadır.

\section{Yöntem}

\section{Araștırma Modeli ve Veri Toplama Araçları}

Bu çalışma, yeni medya ortamlarında izleyici tercihleri ve öneri algoritmaları arasındaki ilişkiyi çözümlemeyi amaçlayan, betimsel bir çalışmadır. Betimsel araştırma modeli; nitel analiz sürecinde ele alınan konuya ilişkin değişkenle- 
rin tanımlanmasına, bu değişkenlerin birbiri ile olan ilişkilerinin ve farklılıklarının incelenmesine olanak tanımaktadır (Özdemir, 2010). Bununla birlikte belirtilen amaç doğrultusunda katılımcıların görüşlerine yer vermek adına, yarı yapılandırılmış soru formu oluşturularak, temel veri toplama yöntemlerinden 'derinlemesine görüşme' gerçekleştirilmiştir. Böylece, kullanıcıların yeni medya mecralarındaki tercih ve tüketim davranışları ile öneri algoritmaları arasındaki ilişki üzerine veriler elde edilmeye çalışılmıştır. Görüşme formunda, "Netflix kullanımında içerik tercih süreçleri, tavsiye sistemlerinin tercih süreçlerindeki etkisi, izleme etkinliğinin düzeyi" gibi konular çerçevesinde hazırlanan on yedi soru yer almaktadır. Bu soruların anlaşılırlığı, yönlendirici olmaması ve amaca uygunluğu açısından diş kontrolün sağlanması amacıyla uzmanların görüşleri alınarak, içerik geçerliliği sağlanmıştır. Katılımcılarla olan görüşmeler, bir çevrimiçi görüşme programı üzerinden birebir gerçekleştirilerek, her bir görüşme kayıt altına alınmıştır. Ayrıca tüm katılımcılardan bu görüşmelerin kayda alınması hususunda rızaları olduğuna ilişkin belge alınmıştır. Diğer yandan görüşme formundan elde edilen verilerle karşılaştırılmak üzere her bir katılımcının rızalarıyla, kendi kişisel Netflix ana ekranlarının ve geçmiş izleme sayfalarının ekran görüntüleri alınmıştır. Çalışma kapsamında kayıt altına alınan katılımcı görüşmelerin deşifresi yapılarak 6 sayfa veri elde edilmiştir. Bu veriler analiz edilirken, araştırmanın amacı doğrultusunda tümevarım yaklaşımıyla tematik kodlama yapılmıştır. Bu bağlamda benzer yanıtlar bir araya getirilerek genellemelere ulaşılmış ve böylece kategoriler-alt kategoriler belirlenmiştir. Bu kategoriler çerçevesinde belirtilen ifadelerin sıklığı tespit edilerek frekans aralıkları oluşturulmuştur. Analizden elde edilen sonuçlar katılımcı görüşleri ve Netflix ekran görüntüleri ile desteklenerek, literatür kısmında yer alan kuramsal bağlamda tartışılmıştır.

\section{Örneklem Grubu}

$\mathrm{Bu}$ araştırmanın çalışma grubunu, 1 yıldan fazla süreyle Netflix üyeliği bulunan, farklı yaş ve meslek gruplarından 8 kullanıcı oluşturmaktadır. Bu açıdan örneklemin amaçlı örneklem tekniği ile belirlendiği söylenebilir. Niteliksel araştırmalarda sıklıkla kullanılan amaçlı örnekleme tekniği, sınırlı kaynakların en etkin biçimde kullanımı için, araştırma konusu hakkında bilgi ve/ veya deneyimleri olan bireylerin belirlenmesinde kullanılmaktadır (Palinkas, ve diğerleri, 2015, s. 534) Amaçlı örneklem tekniğinin kullanılmasındaki temel neden, derinlemesine çalışmaya imkân tanıması açısından amaca uygun niteliklere sahip olduğu düşünülen zengin durumların belirlenmesinde (Büyüköztürk, Kılıç Çakmak, Akgün, Karadeniz, \& Demirel, 2020) kolaylık sağlamasıdır. Çalışmamızda bu teknikten yararlanmamızın asıl gerekçesi, belli bir 
izleme pratiği rutini oluşması açısından en azından bir yıldır düzenli olarak Netflix kullanan bireylere ulaşmak istememizdir. Ayrıca içerik tercihlerinde çeşitliliğin bulunması için seçilen bireylerin farklı demografik özelliklerde olması dikkat edilen başka bir unsur olmuştur. Diğer yandan bulgular kısmında kullanıcıların görüşleri belirtilirken, araştırma etiği kapsamında, katılımcıların isimleri gizli tutularak 'K1, K2, K3,...' şeklinde kodlanmıştır. Katılımcı bilgileri Tablo 1'de yer almaktadır.

Tablo1: Katılımcıların Bilgileri

\begin{tabular}{|c|c|c|l|}
\hline Kod & Cinsiyet & Yaș & Meslek \\
\hline K1 & Erkek & 30 & İlüstratör \\
\hline K2 & Erkek & 37 & Yazılımcı \\
\hline K3 & Kadın & 40 & Çalıșmıyor \\
\hline K4 & Kadın & 36 & Çalıșmıyor \\
\hline K5 & Erkek & 29 & Dijital Pazarlama Uzmanı \\
\hline K6 & Kadın & 27 & Grafiker \\
\hline K7 & Erkek & 42 & Öğretmen \\
\hline K8 & Kadın & 31 & Satın Alma Uzmanı \\
\hline
\end{tabular}

\section{Bulgular}

Görüşmelerden elde edilen veriler analiz sürecinde tasniflenmiş ve iki temel kategoride toplanmıştır. Bu kategoriler altında yine verilen cevaplara göre alt kategoriler oluşturulmuş ve Tablo2' deki şekliyle tablolaştırılmıştır. Ayrıca ana kategoriler ekseninde katılımcı görüşleri tartışılmıştır. 
Tablo 2. Katılımcıların Netflixi kullanma pratikleri ve düzeyleri ile ilgili görüșleri

\begin{tabular}{|c|c|c|c|c|}
\hline Kategori & $\begin{array}{l}\text { Alt } \\
\text { Kategori }\end{array}$ & Genelleștirilmiș ifadeler & $f$ & $\begin{array}{l}\text { Görüș belirten } \\
\text { katılımcılar }\end{array}$ \\
\hline \multirow{7}{*}{ 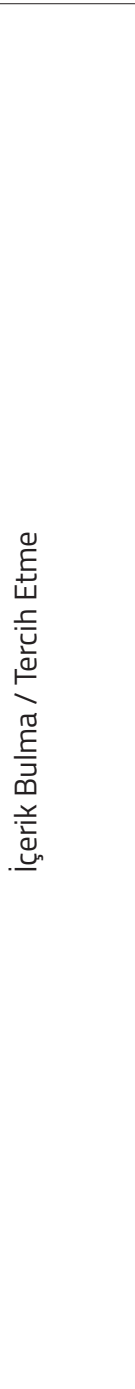 } & $\begin{array}{l}\text { Tavsiye } \\
\text { Sistemleri }\end{array}$ & $\begin{array}{l}\text { Çoğunlukla Netflixin önerilerini } \\
\text { kullanıyorum. Daha önce izlediğim } \\
\text { ve beğendiğim içeriklere benzer } \\
\text { önerilerde bulunuyor. }\end{array}$ & 5 & $\begin{array}{l}\mathrm{K} 1, \mathrm{~K} 2, \mathrm{~K} 3 \\
\mathrm{~K} 5, \mathrm{~K} 6\end{array}$ \\
\hline & \multirow[b]{2}{*}{ Kategoriler } & $\begin{array}{l}\text { İstediğim içeriği bulmakta kategoriler } \\
\text { çok yardımcı oluyor. }\end{array}$ & 5 & $\begin{array}{l}\mathrm{K} 3, \mathrm{~K} 4, \mathrm{~K} 5, \\
\mathrm{~K} 6, \mathrm{~K} 7\end{array}$ \\
\hline & & $\begin{array}{l}\text { Yardımcı olmuyor. Bir içeriği birden } \\
\text { fazla kategoriye atıyor. Çok fazla } \\
\text { detaylandırılmamıș. Sadece önerileri } \\
\text { izliyorum. }\end{array}$ & 3 & $\mathrm{~K} 1, \mathrm{~K} 2$, ,K8 \\
\hline & \multirow[t]{2}{*}{ Arayüz } & $\begin{array}{l}\text { Netflixin arayüzü içerik bulmamı } \\
\text { kolaylaștırıyor. Iç̧erikler ilgimi } \\
\text { çekecek șekilde yer alıyor. }\end{array}$ & 3 & $\mathrm{~K} 3, \mathrm{~K} 4, \mathrm{~K} 6$ \\
\hline & & $\begin{array}{l}\text { Çok memnun değilim. Platformda } \\
\text { kalma süresini uzatmak amaçlı } \\
\text { çok fazla gezdiriyor. İçerik bulmada } \\
\text { yardımcı olmuyor. Önerilerine } \\
\text { yönlendiriyor. }\end{array}$ & 5 & $\begin{array}{l}\mathrm{K} 1, \mathrm{~K} 2, \mathrm{~K} 5, \mathrm{~K} 7, \\
\mathrm{~K} 8\end{array}$ \\
\hline & \multirow[t]{2}{*}{$\begin{array}{l}\text { Listeler ve } \\
\text { Tanıtımlar }\end{array}$} & $\begin{array}{l}\text { Top10, popüler gibi listeler merak } \\
\text { uyandırdığı için ilgi çekici oluyor. } \\
\text { Seyretmediğim bir șey olsa bile } \\
\text { insanlar ne izlemiș diye merak } \\
\text { ediyorum. Tanıtımlar yeni içerik ya } \\
\text { da sezon geldiğinde haberdar olma } \\
\text { açısından kullanıșlı oluyor. }\end{array}$ & 6 & $\begin{array}{l}\mathrm{K} 1, \mathrm{~K} 2, \mathrm{~K} 3, \mathrm{~K} 4 \\
\mathrm{~K} 6, \mathrm{~K} 8\end{array}$ \\
\hline & & $\begin{array}{l}\text { Top10 listesi popüler kültüre hitap } \\
\text { ediyor. Kaliteli içerikler bulunmuyor. } \\
\text { Dikkate almıyorum. Tanıtımlarda } \\
\text { hep kendi yapımlarını tanıtıyor. } \\
\text { İzlemiyorum. }\end{array}$ & 4 & $\mathrm{~K} 3, \mathrm{~K} 5, \mathrm{~K} 7, \mathrm{~K} 8$ \\
\hline
\end{tabular}




\begin{tabular}{|c|c|c|c|c|}
\hline \multirow{6}{*}{ 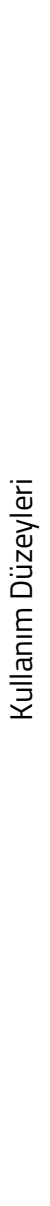 } & $\begin{array}{l}\text { Kullanma } \\
\text { Sıklığı }\end{array}$ & Her gün kesinlikle izliyorum. & 8 & $\begin{array}{l}\mathrm{K} 1, \mathrm{~K} 2, \mathrm{~K} 3, \mathrm{~K} 4, \\
\mathrm{~K} 5, \mathrm{~K} 6, \mathrm{~K} 7, \mathrm{~K} 8\end{array}$ \\
\hline & $\begin{array}{l}\text { Üyelik/ } \\
\text { Takip }\end{array}$ & $\begin{array}{l}\text { Netflixi sosyal medya hesaplarından } \\
\text { takip etmiyorum. } \\
\text { Telefonumdaki uygulaması dıșında } \\
\text { hiç bir hesaptan takip etmiyorum. } \\
\text { Sosyal medyada önüme reklamı } \\
\text { gelirse izliyorum ama takip } \\
\text { etmiyorum. }\end{array}$ & 7 & $\begin{array}{l}\mathrm{K} 1, \mathrm{~K} 2, \mathrm{~K} 4, \mathrm{~K} 5, \\
\mathrm{~K} 6, \mathrm{~K} 7, \mathrm{~K} 8\end{array}$ \\
\hline & $\begin{array}{l}\text { Üyelik/ } \\
\text { Takip }\end{array}$ & $\begin{array}{l}\text { Netflixi sosyal medya hesaplarından } \\
\text { takip etmiyorum. } \\
\text { Telefonumdaki uygulaması dıșında } \\
\text { hiç bir hesaptan takip etmiyorum. } \\
\text { Sosyal medyada önüme reklamı } \\
\text { gelirse izliyorum ama takip } \\
\text { etmiyorum. }\end{array}$ & 7 & $\begin{array}{l}\mathrm{K} 1, \mathrm{~K} 2, \mathrm{~K} 4, \mathrm{~K} 5, \\
\mathrm{~K} 6, \mathrm{~K} 7, \mathrm{~K} 8\end{array}$ \\
\hline & \multirow[t]{2}{*}{$\begin{array}{l}\text { Liste } \\
\text { Olușturma }\end{array}$} & $\begin{array}{l}\text { Liste olușturuyorum. Çünkü Netflix } \\
\text { algoritması olușturduğum listeye } \\
\text { göre öneri sunuyor. İzlemek } \\
\text { istediğim içerikleri topluyorum. }\end{array}$ & 3 & $\mathrm{~K} 2, \mathrm{~K} 4, \mathrm{~K} 6$ \\
\hline & & $\begin{array}{l}\text { Liste olușturmuyorum. Netflix benim } \\
\text { yerime olușturuyor. Yeni içerik } \\
\text { geldiğinde Netflix zaten mail atıyor. }\end{array}$ & 5 & $\begin{array}{l}\mathrm{K} 1, \mathrm{~K} 3, \\
\mathrm{~K} 5, \mathrm{~K} 7, \mathrm{~K} 8\end{array}$ \\
\hline & $\begin{array}{l}\text { Binge } \\
\text { Watching }\end{array}$ & $\begin{array}{l}\text { Bir sezonu bir gecede bitirdiğim oldu. } \\
\text { Asla tek bölüm izleyip bırakmam. } \\
\text { Birkaç bölümü art arda izlerim. }\end{array}$ & 8 & $\begin{array}{l}\mathrm{K} 1, \mathrm{~K} 2, \mathrm{~K} 3, \mathrm{~K} 4, \\
\mathrm{~K} 5, \mathrm{~K} 6, \mathrm{~K} 7, \mathrm{~K} 8\end{array}$ \\
\hline
\end{tabular}

\section{Katılımcıların Netflix'te İçerik Bulma/Tercih Etme Süreçlerine Yönelik Görüșleri}

Katılımcılarla yapılan görüşmeler doğrultusunda belirlenen Netflix'te içerik bulma/tercih etme kategorisine, 'tavsiye sistemleri', 'kategoriler', 'arayüz' ve 'listeler ve tanımlar' başlıklarından oluşan dört alt kategori tanımlanmıştır. Tablo1 incelendiğinde katılımcıların Netflix'te kendilerine uygun içeriği bulma süreçlerinde sıklıkla platformun önerilerini tercih ettiği görülmektedir. 3 katılımcı tavsiye sistemlerini de kullanmakla beraber daha çok bireysel araştırmayla (forumlar, sosyal medya vb) içerik bulduğunu belirtmiştir. Ancak 5 katılımcı içerik bulma ya da tercih etme süreçlerinde neredeyse tamamen tavsiye sistemlerinden yararlandıklarını ve sayfa tarafından önerilen içerikleri izlediklerini söylemişlerdir. Bu bağlamda yapılan görüşmede K1, "Genelde zaten Netflix' in yazılımı tıpkı Instagram ve Youtube gibi sürekli benim izlediğim şeylerin benzerlerini karşıma çıkarıyor, arkadaşlarımdan duyup izledi- 
ğim de oluyor ama çoğunlukla Netflix'in önerdiği içerikleri izliyorum" ifadelerini kullanmıştır. K2 ise "Çoğunlukla Netflix'in önerileri belirleyici oluyor, genel profilime göre eşleştirdiği skora bakıyorum" diyerek tavsiye sistemlerinin izleme davranışı üzerindeki etkisini vurgulamıştır. Konu bağlamında tavsiye sistemlerine yönelik olumlu görüş bildiren katılımcıların hepsi, Netflix önerilerinin kişisel beğenilerine uygun içeriklerden oluştuğunu ya da en azından kendilerinin bu önerileri beğenebileceğini belirtmişlerdir. Bu sonuçlardan yola çıkarak kullanıcıların ne izlediğine yönelik temel kaynağın Netflix' in tavsiye sistemlerinde sunduğu içerikler olduğu söylenebilir.

Diğer bir alt kategori olan 'kategoriler' başlığında, Netflix'in oluşturduğu kategorilerin içerik bulma / tercih etme süreçlerindeki etkisi hakkında katılımcıların görüşlerine yer verilmiştir. Katılımcıların çoğunluğu Netflix' te bulunan kategorilerin, beğenebilecekleri türde içerik bulmada yardımcı olduğunu söylerken, diğer katılımcılar "içeriklerin yanlış türlere göre kategorilendirildiğini" belirterek kullanışsız olduğunu belirtmişlerdir. Bu bağlamda K1 ve K2' nin görüşleri aşağıdaki gibidir:

Kategorileri içerik ararken kullanmıyorum, zaten ben genelde belli kategorileri tercih ettiğim için, Netflix' in önerdiklerini izliyorum.

Kategorilendirmesi çok kötü, çok fazla detaylandırmamışlar. Kategorileri tek satırda göstermeleri kötü, bu nedenle genelde Netflix' in benim için önerdiklerine ve popülerler listesine bakıyorum.

Yukarıda yer alan ifadelerde görüldüğü gibi kategorilendirmeyi kullanmayan kullanıcılar, içerik bulma yöntemi olarak yine Netflix tavsiye sistemlerini kullandıklarını belirtmektedirler. Bu açıdan kategorileri kullanan ya da kullanmayan tüm kullanıcıların bireysel olarak belli bir içeriği aramak yerine, yine Netflix tavsiye sistemleri üzerinden tercihte bulundukları söylenebilir.

Bununla beraber başka bir alt kategori olan "arayüz" ile ilgili olarak katılımcıların çoğu olumsuz görüşler bildirerek Netflix arayüzünden memnun olmadıklarını söylemişlerdir. Yapılan görüşmede K2 "Netflix site içinde özellikle gezdirmeye çalışıyor gibi geliyor, kullanıcı dostu gibi görünse de daha çok platformda kalma süresini uzatma amaçlı yapılmış bir hile gibi geliyor.' ifadelerini kullanarak, Netflix arayüzünün kullanışlı olmadığını ve içeriğe ulaşmada zorlandığını belirtmiştir. K7 ise "Netflix arayüzünün içeriğini geniş gösterme amaçlı tasarlanmış bir aldatmaca olduğunu ve pazarlama stratejisi olarak kişiyi Netflix'te daha uzun süre tutmaya çalıştığını" söylemiştir. 
"Listeler ve tanıtımlar" alt kategorisinde Netflix' in oluşturduğu izleme listeleri ve tanıtımlarla ilgili katılımcıların görüşlerine yer verilmiştir. Bazı katılımcılar listeler ve tanıtımlarla ilgili farklı görüşlere sahip olduğu için iki defa kodlama yapılmıştır. Örneğin K1 "içerik bulma/tercih etme süreçlerinde Netflix' in oluşturduğu listeleri kullanmazken, ana ekranda yer alan tanıtımları dikkate aldığını" belirtmektedir. Bu bağlamda katılımcılar genel olarak Netflix' in oluşturduğu listeleri dikkate alıyorken tanıtımları göz ardı etme eğiliminde olduğu gözlemlenmiştir. Yapılan görüşmede K3 "listelerin izlemediği türde filmlerden oluşmasına rağmen örneğin Top10 listesinde ilk sırada yer alan filmi merak edip açtığını" söylemiştir. K4 ve K6 ise "ilk sıralarda yer alan içeriklerin daha önce insanlar tarafından çokça izlenmiş olmasından dolayı ilgilerini çektiğini ve bu yüzden açıp baktıklarını" ifade etmişlerdir. Genel itibari ile katılımclar özellikle "Top10", "Popüler" gibi listeleri diğer izleyiciler tarafından beğenilmiş olmasından dolayı merak edip incelediklerini vurgulamaktadır. Tanıtımlarla ilgili olarak dört katılımcı yeni içerik ya da sezonları ana ekranda yer alan fragman tanıtımlarından buldukları için olumlu dönüş vermişlerdir. Ancak diğer katılımcılar tanıtımları içerik bulma ya da tercih etmede kullanmadıklarını belirtmişlerdir. Örneğin K5 "Netflix'in tanıtımlarda çoğunlukla kendi yapımlarının fragmanlarını ön plana çıkardığını ve kendisinin de Netflix yapımlarını sevmediği için tanıtımlardan faydalanmadığını" söylemiştir. Bununla beraber K1 "yeni çıkan bir Netflix yapımını tanıtımlardan keşfettiği için Netflix ana ekranında yer alan tanıtımları kullanışlı bulduğunu" ifade etmiştir.

\section{Katılımcıların Netflix'i Kullanma Düzeyleri ile İlgili Görüșleri}

Görüşme formundan elde edilen yanıtların değerlendirildiği bir diğer kategori, Tablo1'de de yer alan 'kullanım düzeyleri' dir. Bu kategori, 'kullanma sıklığ1', 'üyelik/takip', 'liste oluşturma' ve 'binge watching' başlıklarından oluşan dört alt kategoride serimlenmiştir. Bu bağlamda, yapılan görüşmelerde Netflix'in ne kadar sıklıkla kullanıldığıyla ilgili sorulan soruya tüm katılımcılar her gün mutlaka izledikleri yanıtını vermişlerdir. Bir diğer alt kategori olan 'üyelik/takip', katılımcılara Netflix'i sosyal medya mecralarından takip edip etmediği sorularak, platform ile ilgili bilgi alma yolları açısından kullanma düzeyini öğrenmeyi amaçlamaktadır. Bu doğrultuda elde edilen yanıtlar bir katılımcı hariç olumsuz olmuş ve katılımcılar Netflix'i sosyal medyadan takip etmediklerini belirtmişlerdir. Bununla beraber katılımcılar telefon, tablet gibi taşınabilir cihazlarında Netflix uygulamasının olduğunu ve bu nedenle sosyal medya takibine ihtiyaç duymadıklarını söylemişlerdir. K8 ve K6 "sosyal medyada takip etmeseler bile örneğin Instagram'da reklamlarının ya da tanıtımlarının sayfalarına düştüğünü ve merak edip Netflix profilini inceleye- 
rek yeni bir içerik görürlerse kaydettiklerini" ifade etmişlerdir. K5, K1 ve K2 “evde değilken telefonlarındaki uygulamayı kullandıklarını, bildirimleri bu uygulamadan takip ettiklerini ve bu nedenle sosyal medyaya gerek duymadıklarını" söylemişleridir.

'Liste oluşturma' alt kategorisinde katılımcılara Netflix'te kişisel liste oluşturma seçeneğini kullanıp kullanmadıkları sorulmuştur. Gelen yanıtlarda beş katılımcı liste oluşturmadığını söylerken üç katılımcı oluşturduğunu söylemiştir. Bununla beraber hem liste oluşturanlar hem de liste oluşturmayanlar Netflix algoritmasını temel kaynak olarak göstermektedirler. Örneğin liste oluşturduğunu belirtirken K2, temel gerekçe olarak "Kullanıyorum çünkü benim neyi beğendiğimi, neyi izlediğimi takip ederek öneri algoritmasını güçlendiriyor, algoritma hem benim izlediklerimi hem listeme eklediklerimi takip ediyor" İfadelerini kullanmıştır. Bununla beraber liste oluşturmayan K1 "Çünkü Netflix benim yerime oluşturuyor, bu kişi bunu izlediyse kesin bunu da sever diye benim yerime listeliyor, zaman harcamiyorum bununla" diyerek algoritmanın izleme tercihlerindeki önemini vurgulamıştır. Ayrıca bazı katılımcılar izledikleri içeriğin yeni sezonu geldiğinde haberdar olmak için liste oluşturduğunu söylerken, bazı katılımcılar yeni sezonlar hakkında Netflix'in kendisine gönderdiği e-postalardan haberdar oldukları için listeye ihtiyaç duymadıklarını belirtmişlerdir.

Son alt kategorimiz olan 'binge watching' katılımcıların Netflix içeriklerini nasıl tükettiklerini ya da izleme pratikleri nasıl gerçekleştirdiklerini anlamayı amaçlayan soruları içermektedir. Bu doğrultuda yapılan görüşmelerde katılımcılara 'bir dizinin birden fazla bölümünü art arda izleyip izlemedikleri ve eğer izliyorlar ise ne sıklıkla bu şekilde izledikleri' sorulmuştur. Tablo1'de de sunulduğu üzere tüm katılımcılar seri halindeki içerikleri her zaman art arda izlediklerini söylemişlerdir. Katılımcıların izleme pratiklerine yönelik belirttiği görüşler şu şekildedir:

K3 “10-15 bölümü art arda izlediğim bile oldu, genellikle dizileri bu şekilde izliyorum, asla bir bölüm izleyip bırakmıorum."

K4 “Atiye dizisini 1 gecede bitirdim, La Casa Del Papel dizisini dört günde bitirmişimdir, genellikle bu şekilde izlerim."

K5 “6-7 bölümü art arda izlediğim oldu, genelde bir bölümle yetinmiyorum.”

Yukarıda belirtilen ifadelerle beraber katılımcıların seri halindeki içerikleri ortalama birkaç bölüm olmak üzere art arda izlemelerinin temel nedeni 
olarak içeriklerin kısa olmasını ve bir sonraki bölümü merak ettirecek şekilde kurgulanmış olmasını göstermektedirler. Bu bağlamda Netflix' in aşırı izleme davranışını planlayarak içerikleri oluşturduğu düşünülebilir. İzleme pratiği açısından kullanıcıların içeriği tükettiği zamanı örtük olarak biçimlendiren Netflix, ne izleneceğine dair tercihleri de yönlendirebilmektedir. Örneklem grubunda yer alan katılımcıların Netflix hesaplarının arayüzleri ve geçmiş izleme listeleri, görüşme formunda verdikleri cevaplarla birlikte incelendiğinde bu önermeyi açıklayacak anlamlı verilere ulaşılmıştır.

Çalışma kapsamında katılımcıların paylaştıkları Netflix hesaplarının ana ekran, arayüz ve geçmiş izleme listelerinin görüntüleri hem içerik bulma/ tercih etme hem de kullanım düzeyleri kategorilerinde elde edilen cevaplarla birlikte analiz edilmiştir. Bu bağlamda Netflix'in tavsiye sistemleri ve tanıtımlar aracılığıyla ön plana çıkardığı içeriklerde kullanıcı beğenilerinin başat rol oynamadığı söylenebilmektedir. Örneğin katılımcıların ana ekranında tanıtılan yapımların çoğunluğu Netflix orijinal yapımlarından oluşmakta ancak bu içeriklerin genel izleyici kitlesinin beğenisi tarafından belirlendiği söylenmektedir.

Görsel 1'de ana ekranlarını paylaşan katılımcılar arasında K4 "Netflix orijinal yapımlarını sevmediğini ve izlememeyi tercih ettiğini" söyledi halde ana ekranında Netflix yapımı olan bir dizinin tanıtımı yer almaktadır. Diğer yandan hemen hemen tüm katılımcıların ana ekranlarında "Türkiye'de Bugün 1 Numara" gibi listelerde bulunan içerikler yer alırken bu listedeki ilk üç numara Netflix orijinal yapımıdır. Genel izleyici kitlesinin beğenisini toplamış
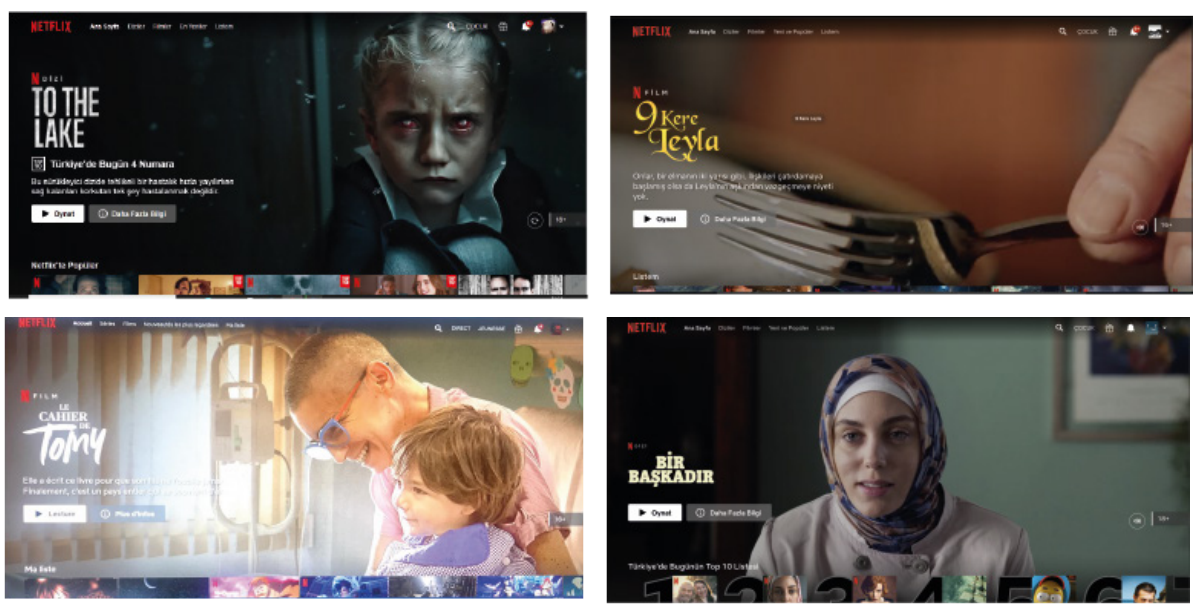

Görsel1: Sırasıyla K8, K7, K1 ve K4'ün ana ekran görüntüleri. 
olduğu söylemi üzerine yapılan tanıtımlar kullanıcıların karar verme süreçlerini yönlendirirken, Netflix orijinal yapımlara yönelik ilgiyi teşvik etmektedir. Ritzer'in McDonaldlaşma teorisini referans alan (Aydın, 2019) Netflix'i denetim açısından değerlendirerek "yapay zekanın kullanıcı beğenilerini takip ederek benzer özelliklerde yeni içerikler sunduğunu ve böylelikle sistem içinde kalmasını sağladığını" belirtmektedir. Ancak algoritmik sistemlerin denetim mekanizmaları, izleyicinin beğenebileceği içerikleri sunmanın ötesinde, izleyici beğenilerini ve tüketim biçimlerini şekillendirmektedir. Dolayısıyla hesaplanabilirlik ve öngörülebilirlik düzeyi arttıkça denetim alanı da genişlemektedir.

Görüşme formundan elde edilen cevaplara göre katılımcıların çoğunluğu içerik bulma yolu olarak tavsiye sistemlerini, kategorileri ve listeleri kulland1ğını belirtmiştir. Ancak paylaştıkları ekran görüntüleri incelendiğinde arayüzün “Türkiye' de Top10”, “Gündemdekiler” gibi listelere öncelik tanıdığı ve bu listelerde de hemen her kullanıcıya aynı içerikleri sunduğu görülmektedir. Bu içeriklerin çoğunu yine Netflix orijinal içerikleri oluştururken, bazı içeriklerin afişlerinin kullanıcıya göre farklılaştırıldığı tespit edilmiştir.

Görsel 2'de sunulan ekran görüntüleri, katılımcıların Netflix arayüzünde yer alan çeşitli listeleri içermektedir. Kullanıcıların içerik bulma/tercih etme yolu olarak gördüğü bu listelerin temelde kişinin beğeni ve geçmiş izleme tercihlerine göre şekillenen kişiselleştirilmiş içeriklerden oluştuğu kabul edilmiştir. Ancak Netflix algoritmaları, ön plana çıkarmak istediği içeriği kullanıcının ilgisini çekecek şekilde yeniden düzenlemekte ve böylece görünürde kullanı-
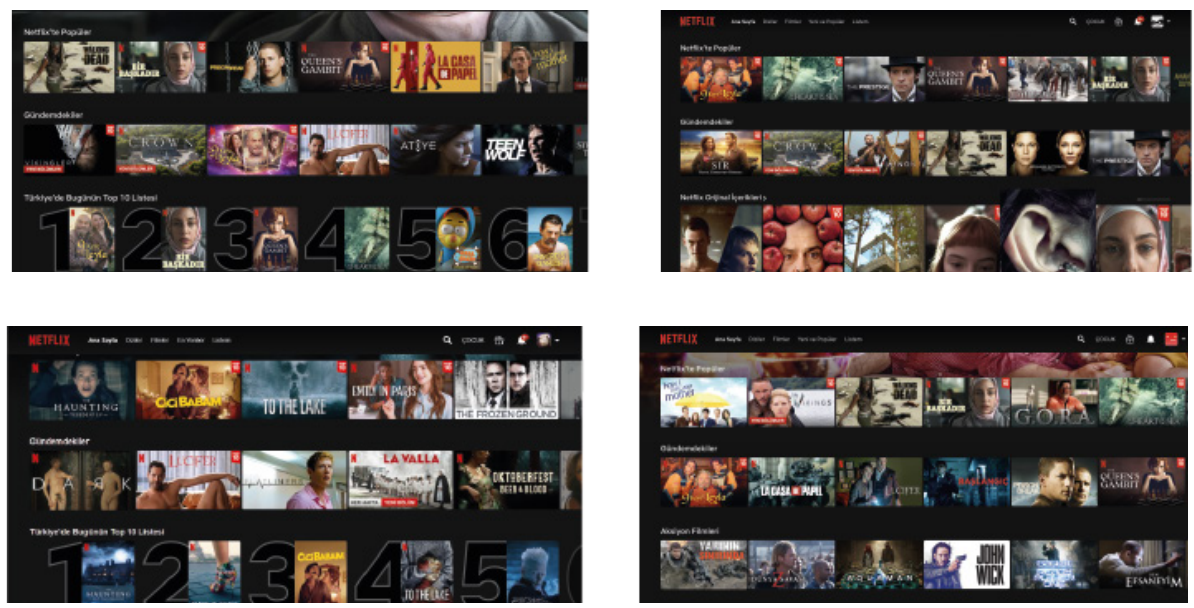

Görsel 2: Sırasıyla K3, K8, K7 ve K5'in arayüz ekran görüntüleri. 
C1 tarafından başlatılan ancak temelde sistemin dayattığı izleme pratiklerini inşa etmektedir. Nitekim katılımcılardan bazılarının (K1, K2, K8), "Netflix' in bir içeriği birden fazla türe atadığ1" yönündeki ifadeleri böyle bir düzenlemenin sonuçlarından biridir. Diğer yandan katılımcıların ekran görüntülerinde de olduğu gibi Netflix, kullanıcılar arasındaki beğeni ve tercih farklılıklarını dikkate alarak bir içeriği birden fazla afiş tasarımı yoluyla sunmaktadır (Chandrashekar, Amat, Basilico, \& Jebara, 2017). Dolayısıyla kişiselleştirme ve 'kullanıcı tercihi/özgürlüğ̈̈' kavramları, sistem tarafından gözetilen ekonomik ve kültürel kaygılar temelinde gerçekleşen algoritmik mantıkla, birer denetim ya da kontrol mekanizması olarak yeniden değerlendirilmelidir.

\section{Sonuç ve Tartıșma}

$\mathrm{Bu}$ çalışma, odak noktasına algoritmaların tüketici kararlarında ne derece etkili olduğunu yerleştirmekte, buna bağlı olarak da kişiselleştirme/özelleştirme gibi uygulamaların algoritmik art alanında izleme pratiklerini nasıl yönlendirdiğini incelemeyi hedeflemiştir. Son y1llarda giderek popülerleşen Netflix' in arayüz tasarımının, kişiselleştirme yoluyla izleyiciyi ne şekilde etkilediğinin üzerinde durularak, elde edilen bulgular bağlamında izleme pratiklerini yönlendirdiği sonucuna ulaşılmıştır. Veriler doğrultusunda ulaşılan bir başka sonuç, kişiselleştirme ve özelleştirme sistemlerinin Netflix' in belirlediği içeriklerin izlenmesini sağlayacak şekilde pazarlama stratejisi olarak kullanıldığıdır. Bu genel çıkarımların yanında çalışmada elde edilen detaylı sonuçlar; kullanıcıların izleyecekleri içeriği bulma/tercih etme yolu olarak Netflix' in tavsiye sistemlerini kullandığı, arayüzün içerik bulmak için kendi önerilerine ve listelerine yönlendirecek şekilde tasarlandığı, bu listelerde ve ana ekrandaki tanıtımlarda Netflix' in ön plana çıkarmak istediği yapımların yer aldığı ve tüm katılımcıların 'binge watching' pratiğine sahip olduğu yönündedir.

Uygulanan görüşme formu sonucunda katılımcıların hemen hepsi izleyecekleri içeriğe karar verme süreçlerinde Netflix'in onlar için tavsiye ettiği içeriklerden yararlandıklarını belirtmiştir. Elde edilen bu sonuç, Netflix'te izlenen içeriklerin yüzde 80'inden fazlasının tavsiye sistemleri aracılığıyla keşfedildiği bilgisiyle örtüşmektedir (Plummer, 2017). Dolayısıyla içerik tercih etmeye yönelik temel kaynağın tavsiye sistemlerinden oluşması, yeni medya platformlarının kullanıcı odaklı ve kullanıcının özgür tercihlerine dayalı bir yapıyı içerdiği kabulünü sarsmaktadır. Bunun yanında görünürde de olsa 'kullanıcı özgürlüğ̈̈ miti'nden hala bahsediliyor olmasının temel nedeni, sistemin kişilerin tercihlerini örtük ya da dolaylı olarak yönlendirmesinden kaynaklandığını söylemek mümkündür. Nitekim izledikleri içerikleri çoğunlukla 
tavsiye edilen içeriklerden seçen katılımcıların çoğu, görüşme formunda yer alan "Netflix'in izleme tercihlerinizi yönlendirdiğini düşünüyor musunuz?" sorusuna karşılık olumsuz görüş bildirmişlerdir. Bu açıdan bakıldı̆̆ında tavsiye sistemlerinin, yalnızca kullanıcının verilerine dayanarak kişiselleştirilmiş içerikleri sunduğu kabul edildiği için, kişiler yönlendirildiklerini ya da maniple edildiklerini düşünmemektedirler. Bu durumu kullanıcıların 'evcilleştirilmesi' olarak gören Siles ve arkadaşları (2019, s. 2), "veri sömürgeciliği” olarak nitelendirdikleri algoritmik öneri sistemlerinin, "kişinin öznelliğini yeniden tanımlayarak onları ideal tüketicilere dönüştürdüğünü" belirtmektedir.

Çalışma esnasında saptanan bir diğer durum ise, Netflix arayüzünde yer alan unsurların, kullanıcıların içerik bulma / karar verme süreçlerine etki edecek şekilde tasarlandığı ve bir araya getirildiğidir. Arayüzde yer alan Netflix listeleri, içerik tanıtımları ya da içeriklerin sunuluş biçimleri, kullanıcıya istenilen içerikleri izlettirmenin yolları olarak görülmektedir. Katılımcılarla yapılan görüşmelerde izleme listeleri ve tanıtımlar hakkındaki genel ifadeler, yeni içerik keşfetme ya da bir içeriğin yeni sezonundan haberdar olma yolu olarak görüldüğü yönündedir. Ancak bununla beraber bazı katılımcılar, Netflix arayüzünün belirli içerikleri ön plana çıkarttığını ya da kullanıcıları tavsiye sistemlerine yönlendirdiğini de eklemişlerdir. Vries'in (2020, s. 23) çalışmasında vurgulandığı üzere, Netflix arayüzü ve önerilerinin "kullanıcıların izlemek istediği içeriklerden değil, Netflix'in kullanıcının izlemesini istediği içeriklerden oluştuğunu" göz önüne aldığımızda, yeni medya ortamlarının kullanıcıya tanıdığı özgürlüğün sınırları daha da daralmaktadır.

Netflix'in araştırma/mühendislik direktörlüğü yapan Amatriarin ve Basilico (2015, s. 391) “kullanıcılar için mümkün olan en iyi öneri deneyimini yaratmak için, oturum açıldığı anda kullanıcının uygulama üzerindeki tüm hareketlerinden veri elde edildiğini ve Netflix kişiselleştirmesinin başladığını" belirtmektedirler. Ancak kullanıcı arayüzleri karşılaştırıldı̆̆ında, aynı içeriğin farklı beğeni tarzlarına sahip olan kişilere, farklı afişlerle, farklı kategorilerde ya da farklı listeler altında sunulduğu görülmektedir. Dolayısıyla yeni medya platformlarını geleneksel medyadan ayıran kişiselleştirme, özelleştirme ya da tercihler gibi terimler, izleyicinin/ kullanıcının öznelliğini odak noktası alarak bireylere daha fazla kontrol ve yetki veriyormuş izlenimi yaratsa da Saphiro'nun (2020, s. 660) "algoritmik bağımlılık" olarak nitelendirdiği bu yeni tüketim ortamının, tüketici kararlarına yardımcı olmaktan ziyade azaltma etkisine sahip olduğu söylenebilir.

Aslında bu bağlamda, "binge watching" davranışı da teşvik edilen bir eylem olarak karşımıza çıkmaktadır. Görüşme formu ile elde edilen bulgular 
düşünüldüğünde tüm kullanıcıların birden fazla bölümü (hatta bazen tüm sezonu) bir gecede bitirdikleri görülmektedir. Öte yandan görüşmeciler, bölüm bittiğinde sistem otomatik olarak diğer bölüme geçtiği için 'zamanın nasıl geçtiğini anlayamadıklarını' da eklemişlerdir. "Binge watching" kavramının bir tür kontrol mekanizması olduğunu (Jenner, 2018) göz önüne aldığımızda, Netflix' in yalnızca ne izleneceğine değil, aynı zamanda nasıl izleneceğine yönelik de belirleyici bir yayıncılık modeli sunduğu ileri sürülebilir.

Yeni medyanın bireyin özgürlüğü ve öznelliği üzerine kurulu olduğu kabulünü tartışmalı bir varsayım olarak gören araştırma kapsamında elde edilen kısıtlı veriler, ticari faaliyetler ekseninde tüketimin yönlendirildiğine, gruplandırıldığına ve buna bağlı olarak kullanıcın bir noktada yine endüstriyel izleyiciye indirgendiğine işaret etmektedir. Daha kapsamlı araştırmalarla ve farklı metodolojiler ile elde edilecek veriler eşliğinde sorunlu söylemin daha fazla tartışılması gerektiği düşünülmektedir.

Video akışlarının İnternette artan hakimiyeti, geleneksel yayın planı ve içerik sahipliğine bağlı televizyon izleme biçimlerinden farklı yapısıyla izleyiciye yeni bir deneyim sunuyor gibi görünmektedir. Öte yandan Netflix, küresel bir içerik üretim ve dağıtım kanalı olarak televizyon sektöründe "Netflix etkisi" olarak da bilinen bir dizi değişimi beraberinde getirmiştir. Bu değişim sürecinde yerleşik televizyon endüstrisinin üretim ve tüketim paradigmaları sorgulanırken, abonelik temelli servislerin küresel pazara hakimiyeti de gün geçtikçe artmaktadır. Kısaca televizyon her yerde kavramı ile de özetlenebilecek bu değişim sürecinde ekranı olan her bir cihaz bir anlamda televizyon içeriğinin tüketilebildiği bir ortam haline dönüşürken "istediğin zaman istediğin yerde istediğin içeriği izle" bir pazarlama sloganı olarak izleyicinin karşısına çıkmaktadır. Ancak üretim sistemlerinin genel doğasının tüketim biçimlerini gruplandırma ve yönlendirme eğilimi bu noktada göz ardı edilmemelidir. 


\section{Kaynakça}

Amatriain, Xavier ve Justin Basilico. 2015. "Recomender System in Industry: A Netflix Case Study." Recommeder Systems Handbook içinde, editörler Francesco Ricci, Lior Rokach ve Bracha Saphira, 385-419. New Yorke: Springer.

Aydın, Oya Şakı. 2019. "Yeni İzleme Biçimleri Ve Netflix İçerikleri: Ritzer'ın Mcdonaldlaşma Tezi Ekseninde Bir Değerlendirme." Uluslararası Sosyal Araştırmalar Dergisi 12 (63): 1167-1172.

http:/ / dx.doi.org/10.17719/jisr.2019.3305

Balc1, Ali. 2015. Sosyal Bilimlerde Araştırma, Yöntem, Teknik ve İlkeler. Ankara: Pagem Akademi.

Büyüköztürk, Şener, Ebru Kılıç Çakmak, Özcan Erkan Akgün, Şirin Karadeniz ve Funda Demirel. 2020. Eğitimde Bilimsel Araştırma Yöntemleri. Ankara: Pagem Akademi Yayıncilık.

Baranseli, Ebru S., Soner Kaya ve Mine Şen. 2018. "60 Yaş Üstü Sosyal Medya Kullanıcılarının Kullanıcı Arayüzü Deneyimlerinin İncelenmesine Yönelik Bir Araştırma Çalışması." Sanat ve Tasarım Dergisi 8 (2): 226- 249.

https: / / doi.org/10.20488/ sanattasarim.530160

Bauman, Zygmunt. 2005. Bireyselleşmiş Toplum. Çeviren Yavuz Alogan. İstanbul: Ayrıntı Yayınları.

Blom, Jan. 2000. "Personalization- A Taxonomy." CHI '00 Extended Abstracts on Human Factors in Computing Systems. New Yorke: ACM. 313-314.

Blom, Jan, ve Andrew Monk. 2009. "Theory of Personalization of Appearance: Why Users Personalize Their PCs and Mobile Phones." Human-Computer Interaction 18 (3): 193-228.

Bondad-Brown, Beverly A., Ronald E. Rice, ve Katy E. Pearce. 2012. "Influences on TV Viewing and Online User-shared Video Use: Demographics, Generations, Contextual Age, Media Use, Motivations, and Audience Activity." Journal of Broadcasting \& Electronic Media 56 (4): 471-493.

https: / / doi.org/10.1080/08838151.2012.732139

Burroughs, Benjamin. 2018. "House of Netflix: Streaming media and digital lore." The International Journal of Media and Culture 17 (1): 1-17.

https: / / doi.org/10.1080/15405702.2017.1343948

Chandrashekar, Ashok, Fernando Amat, Justin Basilico ve Tony Jebara. 2017.

"Artwork Personalization at Netflix." Netflix Technology Blog, 7 Kasım, 2017.

https:/ / netflixtechblog.com/artwork-personalization-c589f074ad76. 
Cöner, Altan. 2003. "Personalization and Customization in Financial Portals." The Journal of American Academy of Business 2 (2): 498-504.

Cox, Christopher M. 2018. "Programming - Flow in the convergence of digital media platforms and television." Critical Studies in Television: The International Journal of Television Studies 13 (4): 438-454. https:// doi.org/10.1177\%2F1749602018796681

Greene, Lauren. 2016. "Pricking the Monster: Netflix and the modification of how and what we watch." Senior Seminar in Film Studies. Columbia University. https://doi.org/10.7916/D8RX9BZ8

Hallinan, Blake, ve Ted Striphas. 2016. "Recommended for you: The Netflix Prize and the production of algorithmic culture." New Media \& Society 18 (1): 117-137. https: / / doi.org/10.1177\%2F1461444814538646

Ho, Shuk, ve Kar-Yan Tam. 2005. "An Empirical Examination of the Effects of Web Personalization at Different Stages of Decision- Making." International Journal of Human-Computer Interaction 19 (1): 3375-3384.

Jenner, Mareike. 2018. Netflix and the Re-invention of Television. Cambridge, UK: Anglia Ruskin University.

Leonard, Andrew. 2013. "How Netflix is turning viewers into puppets." Salon. Erişim tarihi 17 Mart 2021.

https:/ / www.salon.com/2013/02/01/how_netflix_is_turning_viewers_into puppets/

Matrix, Sidneyeve. 2014. "The Netflix Effect: Teens, Binge Watching, and On-Demand Digital Media Trends." The Centre for Research in Young People's Texts and Cultures 6 (1): 119-138. https:// doi.org/10.1353/jeu.2014.0002

Miceli, Gaetano Nino, Francesco Ricotta ve Michele Costabile. 2007. "Customizing customization: A conceptual framework for interactive personalization." Journal of Interactive Marketing 21 (2): 6-25. https://doi.org/10.1002/dir.20076

Montgomery, Alan ve Michael Smith. 2009. "Prospects for Personalization on the Internet." Journal of Interactive Marketing 23 (2): 130-137. https://doi.org/10.1016/j.intmar.2009.02.001

Mutlu, Erol. 2008. İletişim Sözlïğü. Ankara: Ayraç Kitapevi.

Netflix. 2021. "Company Profile." Netflix Investors. Erişim tarihi 17 Mart 2021. https:/ / ir.netflix.net/ir-overview / profile/default.aspx 
Nielsen, Jakob. 2009. "Customization of UIs and Products." Nielsen Norman Group. Erişim tarihi 17 Mart 2021.

https:// www.nngroup.com/articles/customization-of-uis-and-products/

Nielsen, Jakob. 1998. " Personalization is Over-Rated." Nielsen Norman Group.

Erişim tarihi 17 Mart 2021.

https:/ / www.nngroup.com/articles/personalization-is-over-rated/

Özel, Sedat. 2012. "Yeni Medya"nın Temelleri Üzerine Bir Tartışma.” AJIT-e: Online Academic Journal of Information Technology 3 (7): 29-45.

Özel, Sedat. 2015. "Techne'den Teknolojiye Değişen Toplum ve İletişim." İstanbul: Volga Yayıncilik.

Özel, Sedat. 2015. "Bir Yayın Platformu Olarak İnternette Çevrimiçi Videolar ve Kullanıcıların Doyum Faktörleri." Global Media Journal TR Edition 5 (10): 288216.

https: / globalmediajournaltr.yeditepe.edu.tr/sites/default/files/Sedat $\% 20$ O\%CC\%88ZEL.pdf

Palinkas, Lawrence A., Sarah Horwitz, Carla Green , Jennifer P Wisdom, Naihua Duan ve Kimberly Hoagwood. 2015. "Purposeful Sampling for Qualitative Data Collection and Analysis in Mixed Method Implementation Research." Adm Policy Ment Health 42(5): 533-544.

Pilipets, Elena. 2019. "From Netflix Streaming to Netflix and Chill: The (Dis) Connected Body of Serial Binge-Viewer." Social Media + Society 1 (13): 1-13. https: / / doi.org/10.1177\%2F2056305119883426

Plummer, Libby. 2017. "This is how Netflix's top-secret recommendation system works." Erişim tarihi 17 Mart 2021.

https: / / www.wired.co.uk/article/how-do-netflixs-algorithms-workmachine-learning-helps-to-predict-what-viewers-will-like

Rahe, Vanessa, Christopher Buschow ve Daniela Schlütz. 2020. "How users approach novel media products: brand perception of Netflix and Amazon Prime video as signposts within the German subscription-based video-on-demand market." Journal of Media Business Studies 17 (3-4): 8.

Schafer, Ben, John Riedl, ve Joseph Konstan. 2000. "E-Commerce Recommendation Applications." Data Mining and Knowledge Discovery 5 (1-2): 115-153.

Schubert, Petra ve Michael Koch. 2002. "The power of personalization: Customer collaboration and virtual communities." Proceedings of the Eighth Americas Conference on Information Systems (AMCIS). Dallas: Americas Conference on Information Systems (AMCIS). 1953-1965. 
Shapiro, Stephen. 2020. "Algorithmic Television in the Age of Large-scale Customization." Television \& New Media 21(6): 658-663. https: / / doi.org/10.1177\%2F1527476420919691

Siles, Ignacio, Johan Espinoza-Rojas, Adrián Naranjo ve María Fernanda Tristán. 2019. "The Mutual Domestication of Users and Algorithmic Recommendations on Netflix." Communication, Culture \& Critique 12(4): 1-20. https://doi.org/10.1093/ccc/tcz025

Sundar, Shyam ve Anthony Limperos. 2013. "Uses and Grats 2.0: New Gratifications for New Media." Journal of Broadcasting E Electronic Media 57 (4): 504-525. https: / / doi.org/10.1080/08838151.2013.845827

Sundar, Shyam, ve Marathe Sampada. 2010. "Personalization Versus Customization: The Importance of Agency, Privacy, and Power Usage." Human Communication Research 36 (6): 298-322.

Treiblmaier, Horst, Maria Madlberger, Nicolas Knotzer ve Irene Pollach. 2004. "Evaluating Personalization and Customization from an Ethical Point of View: An Empirical Study." Proceedings of the 37th Annual Hawaii International Conference. Hawai: Computer Society Press.

Vries, Britta de. 2020. "The Myth of Personalization." Master Thesis. Chicago: Utrecht University.

Weld, Daniel, Corin Anderson, Pedro Domingos, Oren Etzioni, Krzysztof Gajos, Tessa Lau ve Steve Wolfman. 2003. "Automatically Personalizing User Interfaces." In: Proceedings of the international joint conference on artifi- cial intelligence (IJCAI03). Mexico: Acapulco.

Zündel, Jana. 2019. "Serial skipper: Netflix, binge-watching and the role of paratexts in old and new 'televisions'." Participations: Journal of Audience and Reception Studies 16 (2): 196-219. 